Niniejsza publikacja jest dostęna na licencji Creative Commons. Uznanie autorstwa-Użycie niekomercyjne-Bez utworów zależnych 3.0 Polska. Pewne prawa zastrzeżone na rzecz autora. Zezwala się na wykorzystanie publikacji zgodnie z licencja - pod warunkiem zachowania niniejszej informacji licencyjnej oraz wskazania autora jako właściciela praw do tekstu. Treść licencji jest dostępna na stronie: http://creativecommons.org/licenses/by-nc-nd/3.0/pl/

Lingwistyka Stosowana 19: 4/2016, 1-22

\author{
Agnieszka ANDRYCHOWICZ-TROJANOWSKA
}

Uniwersytet Warszawski

\title{
Uczniowskie sposoby i strategie pracy z podręcznikiem do nauki języka angielskiego w obrazowaniu okulograficznym
}

\begin{abstract}
:
Secondary school students' ways and strategies of working with the textbook of English: an eyetracking study

The following article is devoted to the results of the second out of two eye-tracking pilot studies that were aimed at analysing the way the Polish secondary school students work with the English textbook material and at describing the strategies of completing the given tasks the students choose.

The article gives some very basic theoretical background to the eye-tracking terminology (eye movement, fixation, saccade, area of interest) and presents the results of the pilot study based on a few basic parameters related to the movement of the eyes (i.e. fixation count total, fixation time total, dwell time total) and the data prepared by the software (and then analyzed by the author of the research) in the form of transition matrices, sequence charts and event statistics. The pilot study conclusions are listed at the very end of the article.
\end{abstract}

\section{Wstęp}

Na łamach 14. numeru „Lingwistyki Stosowanej” przedstawiłam pierwsze z dwóch przeprowadzonych przeze mnie pilotażowych badań uwagi wzrokowej uczniów licealnych podczas pracy z podręcznikiem do nauki języka angielskiego (A. Andrychowicz-Trojanowska 2015a). W niniejszym artykule przedstawiam drugie, ostatnie, badanie pilotażowe i wskazuję te parametry okulograficzne, które miały szczególne zastosowanie w analizie zapisów tego badania.

\section{Okulografia - podstawowe pojęcia}

Okulograf jest urządzeniem rejestrującym ruch gałek ocznych za pomocą systemu pomiarowego podłączonego lub zintegrowanego z komputerem, dzięki czemu określa on kierunki linii wzroku (rejestruje, gdzie pada wzrok, w jakiej kolejności, na jak długo) (S. Grucza 2011: 156; więcej: K. Holmqvist et al. 2011, A. Duchowski 2007). Pozwala to określić, gdzie w danym momencie padał wzrok badanego.

Podstawowymi pojęciami dla okulografii są te związane z ruchem oka, czyli przede wszystkim fiksacje (tj. zatrzymanie ruchu gałek ocznych na fragmencie znaj- 
dującym się na linii wzroku) i sakady ${ }^{l}$ (tj. przeniesienia wzroku z jednego do drugiego punktu fiksacji) (por. M. Płużyczka 2015). Każda sakada kończy się fiksacją, w trakcie której rejestrowane są dane dotyczące poziomu pobudzenia fotoreceptorów w siatkówkach oczu, które są następnie przekazywane do mózgu jako informacja o widzianym w tym momencie fragmencie sceny wizualnej (P. Francuz 2013: 104). Należy jednak pamiętać, że oko wykonuje różne ruchy, które można podzielić na trzy podstawowe grupy: mikroruchy (ruchy fiksacyjne), ruchy mimowolne (odruchy) i ruchy kadrujące.

Mikroruchy, do których zaliczane są mikrosakady (ang. microsaccade), mikrod$r y f t$ (ang. ocular drift), mikrodrżenie (ang. ocular microtremor; inaczej tremor, oczopląs fizjologiczny), to ruchy wykonywane przez oko w momencie fiksacji (są to mimowolne ruchy fiksacyjne), których zadaniem jest przeciwdziałanie adaptacji fotoreceptorów do tego samego oświetlenia w trakcie fiksacji. Ruchy mimowolne, inaczej odruchy, służą utrzymywaniu spojrzenia na wybranym obiekcie. Odruch przedsionkowo-oczny, ang. vestibulo-ocular reflex, utrzymuje spojrzenie na obiekcie $\mathrm{w}$ trakcie poruszania głową; odruch optokinetyczny, ang. optokinetic reflex, utrzymuje spojrzenie na obiekcie, gdy obiekt/obserwator obiektu porusza się bardzo szybko wobec nieruchomego obserwatora/obiektu, odpowiednio; odruch wergencyj$n y$, ang. vergence reflex, utrzymuje spojrzenie na obiekcie/obserwatorze obiektu, który zbliża się (ruchy konwergencyjne, ang. convergence) lub oddala (ruchy dywergencyjne, ang. divergence reflex) od obserwatora/obiektu. Do ruchów kadrujących natomiast należą sakady i ruchy podążania. Sakady, inaczej ruchy skokowe, pozycjonują osie widzenia obu gałek ocznych na danym fragmencie sceny wizualnej. Ruchy podążania natomiast to takie ruchy, w trakcie których oczy poruszają się z taką samą prędkością, z jaką porusza się obserwowany fragment sceny wizualnej (P. Francuz 2013: 97-99), jakby śledząc go.

W niniejszym opracowaniu będę wykorzystywała jedynie fiksacje i sakady. Zainteresowanych szczegółowym opisem wspomnianych wyżej zjawisk odsyłam do bogatej literatury tematu (np. P. Francuz 2013, R.J. Leigh/ D.S. Zee 2006, S. Martinez-Conde et al. 2004, S. Martinez-Conde et al. 2009, M. Rolfs 2009, R. Engbert/ R. Kliegl 2004, R. Engbert 2006). Ważne, aby czytelnik zdawał sobie sprawę z niezwykłej złożoności, jaka charakteryzuje proces postrzegania wzrokowego i samej pracy oka, a jednocześnie aby pamiętał, że ruchy oka są bezpośrednim odzwierciedleniem procesów przetwarzania językowego (P. Soluch/ A. Tarnowski 2013: 129).

\section{Badanie}

\subsection{Cel}

Celem przeprowadzonych badań pilotażowych, jak również nieodległych w czasie przyszłych badań właściwych jest sprawdzenie, jakie elementy graficzne podręczni-

\footnotetext{
${ }^{1} \mathrm{~W}$ polskojęzycznej literaturze przedmiotu można również spotkać zapis sakkada (zapis wzorowany na angielskim saccade).
} 
ka do nauki języka angielskiego i na jakim etapie pracy z podręcznikiem mają dla uczniów znaczenie (innymi słowy - na co i kiedy uczeń patrzy), a w konsekwencji w jaki sposób wpływa to na efektywność procesu glottodydaktycznego i które elementy materiałów są glottodydaktycznie (nie)relewantne, tj. (nie)istotne. Ponadto chcę sprawdzić, jakie są uczniowskie strategie wykonywania poleceń z podręcznika, a w dalszej perspektywie - jak można dostosować materiał glottodydaktyczny do tych strategii uczniowskich.

\subsection{Uczestnicy}

Drugie badanie pilotażowe, będące przedmiotem niniejszego artykułu, zostało przeprowadzone w kwietniu 2015 roku w jednym z warszawskich liceów ogólnokształcących. W badaniu tym wzięło udział 21 uczniów (w tym 8 osób ze stwierdzoną dysleksją), których zarejestrowane wyniki zostały poddane analizie. Uczniowie reprezentowali wszystkie trzy oddziały (kl. I, II, III) i znali język angielski na poziomach od Pre-Intermediate do Upper-Intermediate. 17 uczestników tego badania brało udział w pierwszym badaniu pilotażowym w styczniu $2015 \mathrm{r}$.

\subsection{Material i przebieg badania}

Uczniowie pracowali $\mathrm{z}$ materiałami $\mathrm{w}$ wersji elektronicznej, wyświetlanymi na ekranie LCD komputera. Materiały składały się z części czarno-białej i kolorowej. Obydwie części zostały opracowane i przygotowane przeze mnie na podstawie analizy wybranych 13 podręczników trzech wiodących na polskim rynku wydawnictw (Oxford, Pearson, Express Publishing) oraz na podstawie wniosków i założeń z pierwszego badania pilotażowego (A. Andrychowicz-Trojanowska 2015a, A. Andrychowicz-Trojanowska 2015b). Pierwsza wyświetlana część, czarno-biała, imitowała swoim wyglądem i układem zeszyt ćwiczeń do języka angielskiego (podsekcja Reading), a druga część, kolorowa, - podręcznik (podsekcja Reading). Uczniowie siedzieli w odległości ok. $60 \mathrm{~cm}$ od 22-calowego ekranu komputera. Do jego dolnej obudowy przymocowana była mini-kamera (okulograf). Ruch gałek ocznych był rejestrowany z częstotliwością próbkowania $250 \mathrm{~Hz}$. Przed przystąpieniem do badania każdy uczestnik otrzymał ustną instrukcję dotyczącą sprzętu oraz przebiegu badania. Badanie rozpoczynało się kalibracją (tj. dostosowaniem urządzenia do specyfiki ruchu gałek ocznych konkretnego badanego), następnie na ekranie pojawiał się materiał czarno-biały i padało ustne polecenie wypowiadane przeze mnie „Wykonaj zadanie 2. Odpowiedzi podaj na głos". Po udzieleniu przez badanego ostatniej odpowiedzi do tego zadania wypowiadałam drugie polecenie (,Wykonaj zadanie 3. Odpowiedzi podaj na głos"). Po zakończeniu udzielania odpowiedzi na ekranie wyświetlałam drugą, kolorową, część materiałów i wypowiadałam polecenie „Wykonaj zadanie 2. Odpowiedzi podaj na głos", a następnie, po skończeniu przez ucznia udzielania odpowiedzi, drugie polecenie (,Wykonaj zadanie 3. Odpowiedzi podaj na głos”). Należy podkreślić, że czas na wykonanie poleceń był nielimitowany, aby nie wprowadzać dodatkowego czynnika, który mógłby mieć wpływ na zachowanie uczniów, a tym samym wpłynąć na wynik badania. Ostatnim etapem badania było 
udzielenie odpowiedzi na pytania $\mathrm{w}$ ankiecie papierowej. Pytania te dotyczyły badania $\mathrm{i}$ jego przebiegu (ankieta $\mathrm{w}$ drugim, opisywanym tu badaniu pilotażowym została poszerzona o jedno pytanie). W niniejszym artykule nie zostaną zaprezentowane wyniki z części ankietowej - zainteresowanych nimi czytelników odsyłam do A. Andrychowicz-Trojanowska 2016 i 2015a.

\subsection{Wybrane parametry okulograficzne}

Przeprowadzone badanie i zarejestrowane wyniki zostały przeanalizowane na 2 poziomach (czytelników zainteresowanych innymi możliwymi do wykorzystania parametrami odsyłam do moich wcześniejszych opracowań: A. AndrychowiczTrojanowska 2015b, A. Andrychowicz-Trojanowska 2016). Pierwszy z nich dotyczy samego materiału glottodydaktycznego, jakim jest podręcznik, z punktu widzenia jego układu. W tym celu należy skupić się na danych otrzymanych dla obszarów zainteresowania (AOI - patrz 2.4.1). Spośród wielu generowanych przez oprogramowanie parametrów szczególne zastosowanie na tym poziomie mają: całkowita liczba fiksacji na danym AOI (ang. fixation count total), całkowity czas fiksacji na danym AOI (ang. fixation time total), całkowity czas przebywania wzrokiem na danym AOI (ang. dwell time total). Drugi poziom dotyczy sposobu realizacji polecenia i sprowadza się do przeanalizowania strategii, jakie wybiera i jakimi kieruje się uczeń w trakcie wykonywania zadania. Do takiej analizy można wykorzystać macierz przejść pomiędzy AOI (ang. transition matrix), kolejność „wydarzeń wzrokowych" (ang. AOI sequence chart) oraz dane liczbowe dla wydarzeń wzrokowych (ang. event statistics). Powyższe parametry zostaną opisane w dalszej części artykułu.

\subsubsection{Obszary zainteresowania (AOI)}

Ze względu na możliwości techniczne, jakie daje okulograf oraz na cel badań tego typu bardzo ważnym pojęciem jest obszar zainteresowania (ang. area of interest, AOI), czyli te fragmenty prezentowanego materiału, którymi badacz jest szczególnie zainteresowany (w niniejszym artykule wymiennie będą stosowane określenia $o b$ szar zainteresowania i AOI). Należy zauważyć, że istnieje możliwość dowolnego kształtowania tych obszarów na każdym etapie analizy wyników, w zależności od potrzeb.

W badaniach uwagi wzrokowej uczniów $\mathrm{w}$ trakcie pracy $\mathrm{z}$ podręcznikiem do nauki języka angielskiego znajduje uzasadnienie podział (zaproponowany przeze mnie we wcześniejszych opracowaniach) na obszary związane i niezwiązane z wykonywanymi poleceniami (por. A. Andrychowicz-Trojanowska 2015b i 2016). Podstawową dla tego rozróżnienia kategorią będzie obszar pracy, rozumiany przez mnie jako wszystkie te fragmenty prezentowanego materiału, które są bezpośrednio związane z wykonywanym zadaniem, czyli wymuszają przynajmniej jednorazowe skupienie uwagi wzrokowej na sobie. W konsekwencji, wyznaczone obszary zainteresowania będą należały albo do obszaru pracy ( $\mathrm{tj}$. te, na które trzeba spojrzeć przynajmniej raz, aby móc wykonać polecenie), albo będą leżały poza obszarem pracy (tj. te, które są niejako dodatkowe, nie mają związku $\mathrm{z}$ wykonywanym poleceniem). 
Poniżej przedstawiam obszary zainteresowania z obszaru pracy i spoza obszaru pracy w obydwu wyświetlanych częściach materiałów (wszystkie poniższe ilustracje są moim własnym opracowaniem; teksty i treść zadań zaczerpnęłam z opracowania Oxford Excellence for Matura. New Exam Builder wyd. Oxford, dopuszczonego do użytku szkolnego przez MEN - patrz w bibliografii: Quintana et al. 2011):
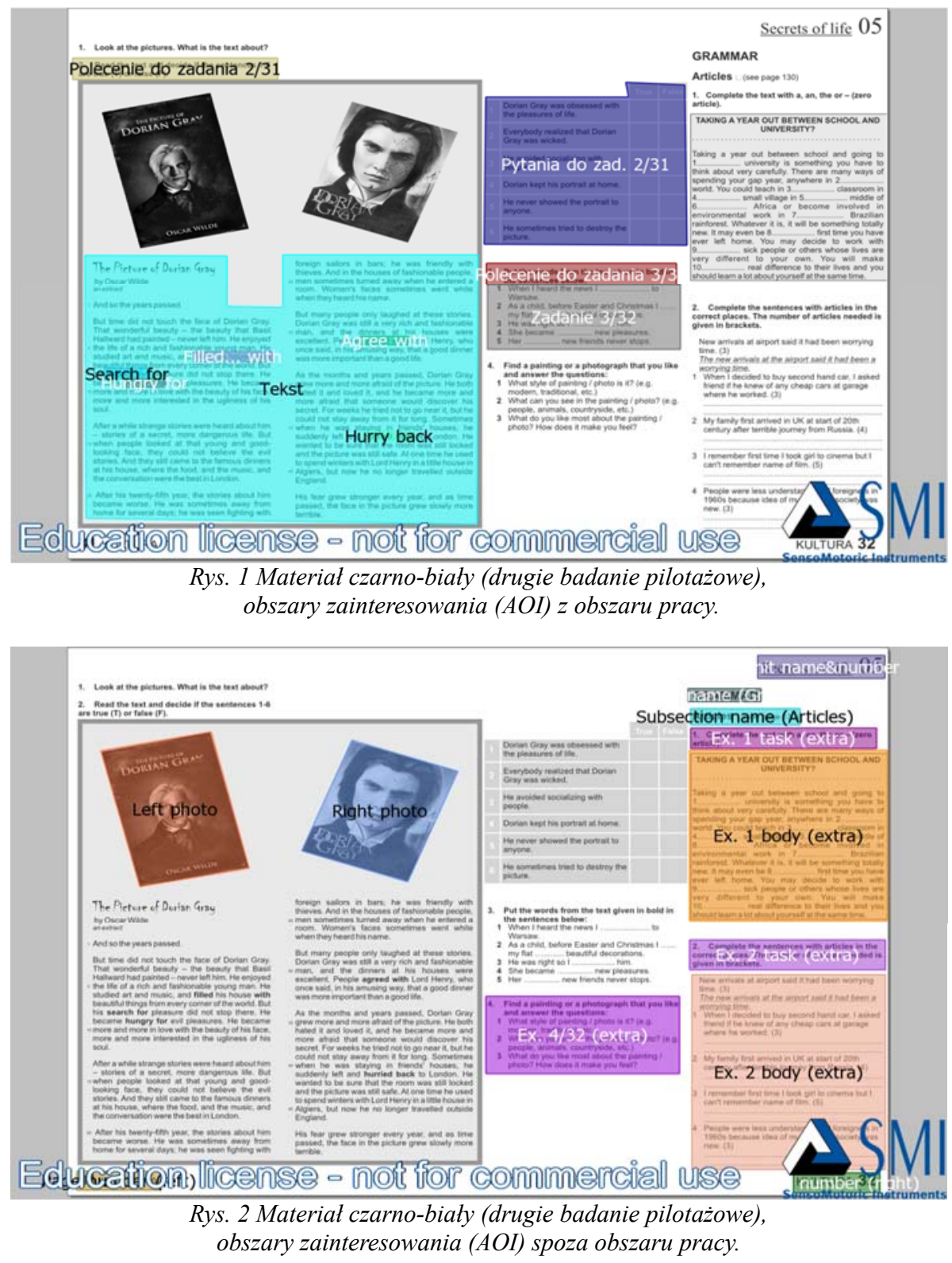

Lingwistyka Stosowana/ Applied Linguistics/ Angewandte Linguistik: www.ls.uw.edu.pl 

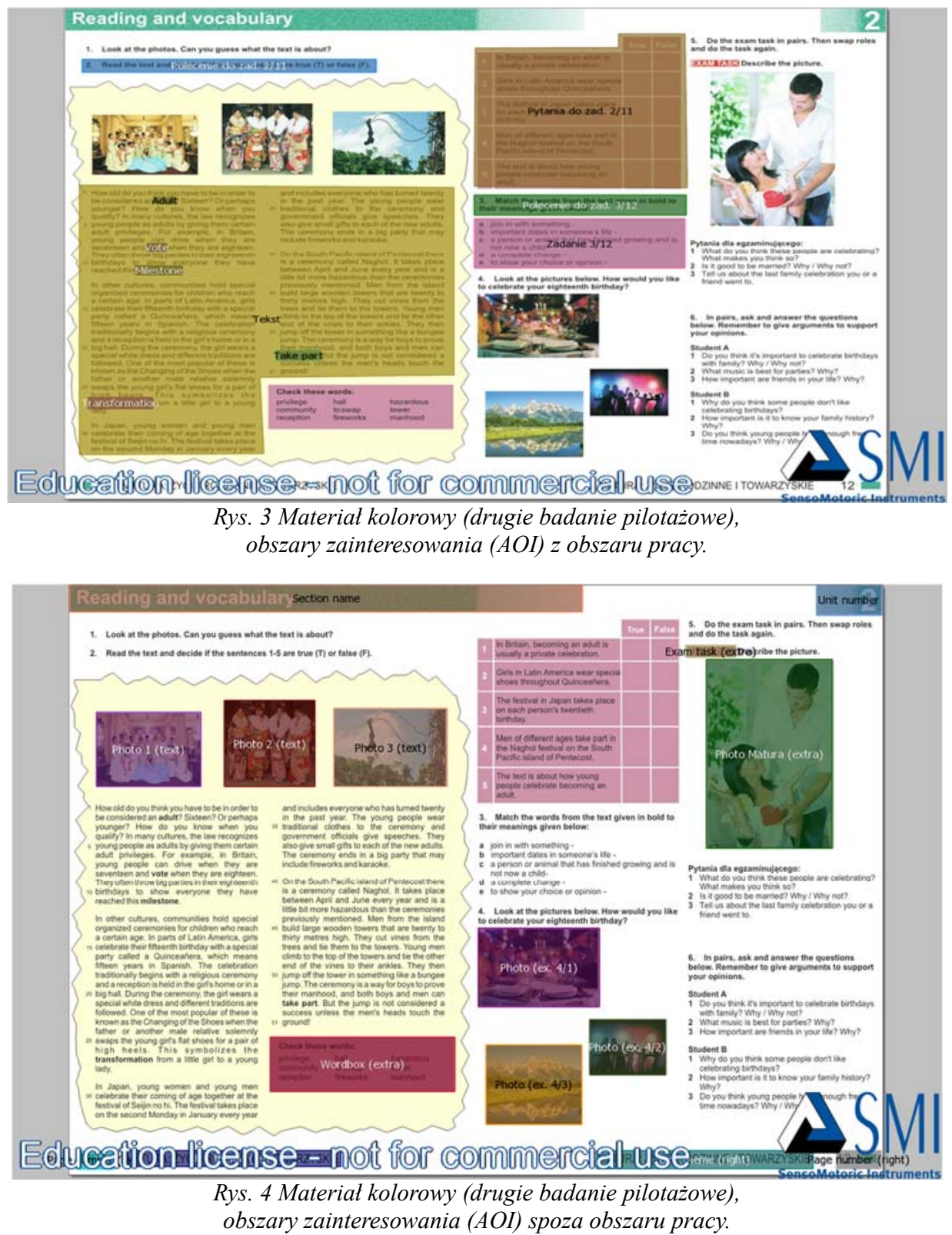

Ze względu na cel prowadzonych badań szczególnie interesujący dla mnie jest ewentualny wpływ elementów graficznych, rozumianych jako ilustracje, rysunki, elementy kolorystyczne, ale również numery stron, nagłówki itp., na sposób pracy z podręcznikiem, dlatego też w materiale kolorowym obszarami zainteresowania były wszystkie elementy tego typu (nie znalazły się w grupie AOI polecenia do zadań dodatkowych). Jednak mimo to w przypadku materiału czarno-białego obszarami zainteresowania były również polecenia do zadań dodatkowych i ich treść, co wynikało z zastosowanego (na wzór niektórych przeanalizowanych podręczników) po- 
wtórzenia tej samej numeracji zadań (w materiale tym były dwa ćwiczenia o numerze 1 i dwa ćwiczenia o numerze 2). Tym samym chciałam sprawdzić, czy i na ile tego typu numeracja (stosowana w niektórych podręcznikach) utrudnia badanym sprawne poruszanie się po materiale.

\subsubsection{Calkowita liczba fiksacji}

Całkowita liczba fiksacji na danym obszarze zainteresowania (ang. fixation count total) jest parametrem pokazującym liczbę wszystkich fiksacji, tj. skupień wzroku, na danym AOI. Wartości te mogą być przedstawiane dla poszczególnych badanych, dla wszystkich lub dla wybranych badanych - w przypadku poniższej analizy wartości prezentowane są dla wszystkich badanych łącznie, bez podziału na podgrupy.

Poniższa tabela przedstawia całkowitą liczbę fiksacji na AOI z materiału czarnobiałego. Wartości zostały przedstawione w kolejności od największej do najmniejszej, wytłuszczono obszary zainteresowania należące do obszaru pracy.

\begin{tabular}{|l|r|}
\hline \multicolumn{1}{|c|}{ AOI } & Calkowita liczba fiksacji \\
\hline Tekst & 12763 \\
\hline Pytania do zad. 2/31 & 3193 \\
\hline Zadanie 3/32 & 2948 \\
\hline Polecenie do zad. 3/32 & 704 \\
\hline Filled... with & 320 \\
\hline Search for & 228 \\
\hline Hungry for & 214 \\
\hline Right photo & 175 \\
\hline Left photo & 156 \\
\hline Agree with & 151 \\
\hline Polecenie do zad. 2/31 & 150 \\
\hline Hurry back & 121 \\
\hline Ex. 4/32 (extra) & 116 \\
\hline Ex. 2/32 body (extra) & 84 \\
\hline Ex. 2/32 task (extra) & 75 \\
\hline Ex. 1/32 body (extra) & 73 \\
\hline Page number (left) & 33 \\
\hline Ex. 1/32 task (extra) & 25 \\
\hline Subsection name (Articles) & 13 \\
\hline Section name (Grammar) & 8 \\
\hline Unit name\&number & 2 \\
\hline Page number (right) & 2 \\
\hline
\end{tabular}

Tab. 1 Całkowita liczba fiksacji (malejaco) na wszystkich AOI, materiat czarno-biały, drugie badanie pilotażowe (wyttuszczono AOI z obszaru pracy). 
Na podstawie powyższej tabeli można zauważyć, że w przypadku materiału czarno-białego na każdym obszarze zainteresowania odnotowano fiksacje, co oznacza, że nie było AOI, na które nikt nie zwrócił uwagi wzrokowej. Ponadto widać, że na obszarze treści pytań do wykonywanych zadań (Pytania do zad. 2/31 i Zadanie 3/32) liczba odnotowanych fiksacji była wysoka, co może świadczyć o wczytywaniu się w ich treść. Co ciekawe, w porównaniu z powyższym znacznie mniejszą liczbę skupień wzroku odnotowano na poleceniach do obydwu zadań, co może zaskakiwać - na poleceniu do zad. 2/31 liczba skupień wzroku była ponad 4,5-krotnie mniejsza niż w przypadku polecenia do zad. 3/32. Jest to bardzo istotne spostrzeżenie z punktu widzenia sposobu pracy z podręcznikiem, dlatego też będę do niego kilkukrotnie powracać w dalszej części artykułu.

Należy również odnotować dość dużą liczbę skupień wzroku na zdjęciach umieszczonych nad tekstem, które wiązały się z treścią tekstu, ale nie należały do obszaru pracy (Left photo, Right photo). Warta podkreślenia jest także liczba fiksacji na zadaniu 4/32 (Ex. 4/32 extra), nienależącym do obszaru pracy, ale umiejscowionym bezpośrednio pod nim. Ponadto pewna liczba skupień wzroku została odnotowana tak na poleceniach, jak i na treści zadań z części gramatycznej, które miały tę samą numerację, co zadania właściwe.

W materiale kolorowym całkowita liczba fiksacji dla każdego AOI wygląda następująco:

\begin{tabular}{|l|l|}
\hline \multicolumn{1}{|c|}{ AOI } & Całkowita liczba fiksacji \\
\hline Tekst & 13280 \\
\hline Pytania do zad. 2/11 & 3599 \\
\hline Zadanie 3/12 & 2553 \\
\hline Polecenie do zad. 3/12 & 497 \\
\hline Wordbox (extra) & 272 \\
\hline Milestone & 201 \\
\hline Transformation & 191 \\
\hline Take part & 147 \\
\hline Photo 3 (text) & 112 \\
\hline Vote & 88 \\
\hline Section name & 83 \\
\hline Photo 2 (text) & 77 \\
\hline Photo 1 (text) & 75 \\
\hline Adult & 69 \\
\hline Photo (ex. 4/1) & 69 \\
\hline Photo Matura (extra) & 51 \\
\hline Polecenie do zad. 2/11 & 44 \\
\hline Photo (ex. 4/2) & 8 \\
\hline Exam task (extra) & 2 \\
\hline Unit theme (left) & 2 \\
\hline
\end{tabular}




\begin{tabular}{|l|l|}
\hline Photo (ex. 4/3) & 1 \\
\hline Unit number & 0 \\
\hline Unit theme (right) & 0 \\
\hline Page number (left) & 0 \\
\hline Page number (right) & 0 \\
\hline
\end{tabular}

Tab. 2 Catkowita liczba fiksacji (malejąco) na wszystkich AOI, materiat kolorowy, drugie badanie pilotażowe (wytluszczono AOI z obszaru pracy).

Podobnie jak w Tabeli 1, także tu wartości liczbowe zostały ułożone malejąco, a wytłuszczono obszary zainteresowania należące do obszaru pracy. Wnioski, jakie wypływają z Tabeli 2 sprowadzają się do kilku obserwacji. Po pierwsze, wśród wyodrębnionych AOI są takie, na których nie odnotowano żadnej fiksacji, co oznacza, że nikt z badanych nie spojrzał na nie. W materiale kolorowym są to 4 obszary spoza obszaru pracy. Po drugie, na poleceniu do zad. 2/11 liczba fiksacji była ponad jedenastokrotnie mniejsza niż na poleceniu do zad. 3/12 (obydwa AOI należały do obszaru pracy). Po trzecie, stosunkowo dużą liczbę fiksacji odnotowano na tabelce (Wordbox extra), która znalazła się pod tekstem i nie miała związku z poleceniami (należała do AOI spoza obszaru pracy). Po czwarte, liczba fiksacji na (podkreślonych w tekście) słowach jest różna dla słów krótkich i długich. Dla słów krótkich (1-2 sylabowych) odnotowana liczba fiksacji jest prawie trzykrotnie niższa niż na słowach kilkusylabowych (transformation, milestone), często obcych i trudnych do wymówienia, a odpowiedzi do zadań udzielane były ustnie, więc badani musieli przeczytać i wymówić te słowa na głos. Wniosek ten ma potwierdzenie w badaniach nad sposobem czytania (np. Rayner 1998). Po piąte, należy zwrócić uwagę na stosunkowo dużą liczbę fiksacji na zdjęciach znajdujących się nad tekstem oraz w ćwiczeniu 4, z których żadne (Photo 1 text, Photo 2 text, Photo 3 text) nie należało do obszaru pracy. Podobnie wyróżnia się pod tym względem górne zdjęcie z ćwiczenia 4 spoza obszaru pracy (Photo ex. 4/1). Zdjęcie to znajdowało się blisko obszaru pracy - na kolejnych zdjęciach z tego ćwiczenia, które były bardziej oddalone od obszaru pracy, liczba fiksacji jest znacząco mniejsza.

\subsubsection{Całkowity czas fiksacji i całkowity czas przebywania}

Całkowity czas fiksacji (ang. fixation time total) jest parametrem pokazującym łączną długość wszystkich fiksacji (wyrażoną w milisekundach) na danym AOI dla wybranych badanych. Całkowity czas przebywania (wzrokiem) ${ }^{2}$ natomiast jest sumą czasu trwania wszystkich fiksacji i wszystkich sakad na danym AOI dla wybranych badanych (wyrażoną w milisekundach), co oznacza, że parametr ten nie może być mniejszy od całkowitego czasu fiksacji. Wszystkie prezentowane wartości podawane są dla wszystkich badanych łącznie, bez podziału na podgrupy. Obydwa parametry zostały przedstawione razem dla każdego AOI, z zachowaniem podziału na AOI

${ }^{2}$ Jest to moja propozycja thumaczenia określenia ,dwell time total”. W innych pracach można spotkać np. określenie „czas wszystkich fiksacji i sakad” (dla „dwell time”) - por. M. Płużyczka 2015. 
z i spoza obszaru pracy. Należy jednak pamiętać, że skale na osi pionowej obydwu wykresów dla tego samego materiału różnią się (skala dla materiału czarno-białego na Rys. 5 jest 111-krotnie większa niż na Rys. 6; skala dla materiału kolorowego na Rys. 7 jest 41-krotnie większa niż na Rys. 8), co musi być brane pod uwagę podczas porównywania wyników między sobą.

Wartości obydwu parametrów dla materiału czarno-białego wyglądają następująco:

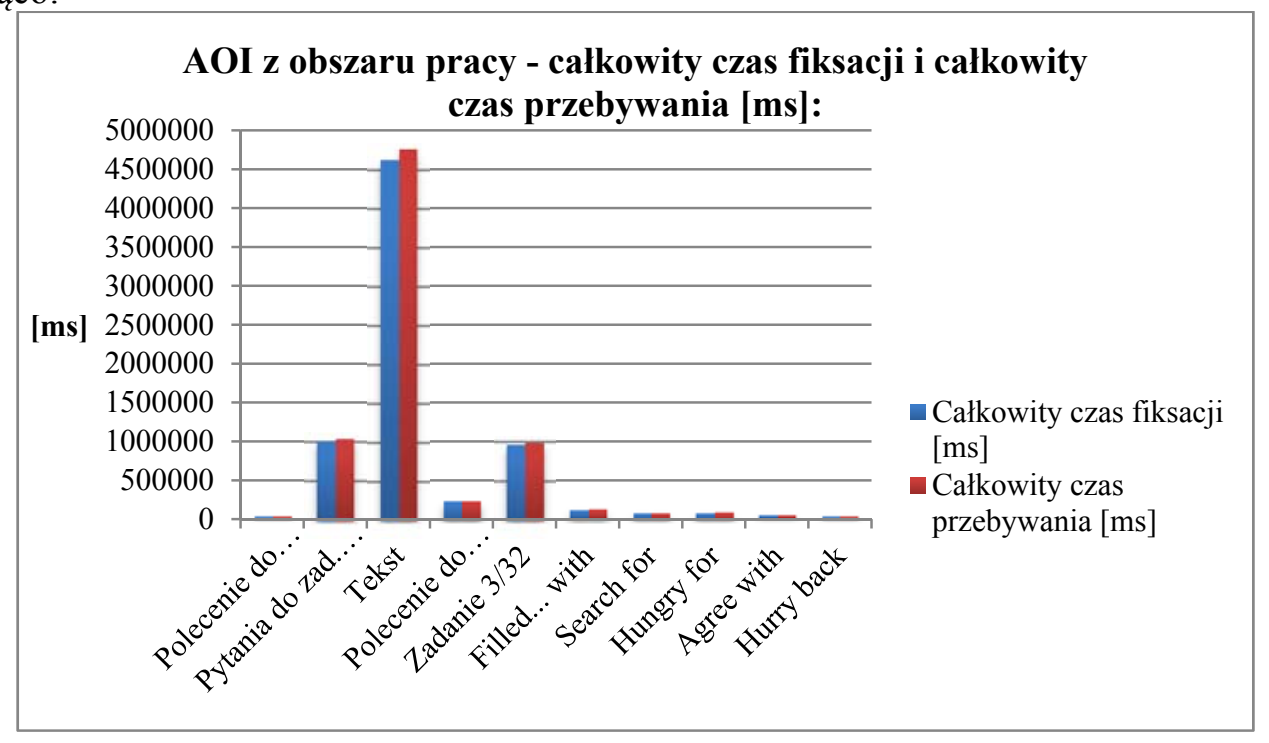

Rys. 5 Calkowity czas fiksacji i catkowity czas przebywania [ms] dla AOI z obszaru pracy, materiat czarno-biaty, drugie badanie pilotażowe.

Na powyższym schemacie wyróżnia się AOI Tekst, dla którego wartości obydwu parametrów są największe, co nie może dziwić ze względu na charakter poleceń, które opierały się na informacjach z tekstu, a co za tym idzie - na konieczności przeczytania i być może powrotu/powrotów wzrokiem (tzw. rewizyty) w celu weryfikacji udzielanych odpowiedzi. Widoczne jest podobieństwo czasu fiksacji i czasu przebywania na treści pytań do obydwu zadań. Ponadto widać, że wartości obydwu parametrów na poleceniach do zadań (szczególnie na poleceniu do zad. 2/31) są niewielkie, co może sugerować pobieżne zapoznanie się z ich treścią. Więcej informacji na ten temat dostarczą dane m.in. z macierzy przejść, opisywanej dalej. 


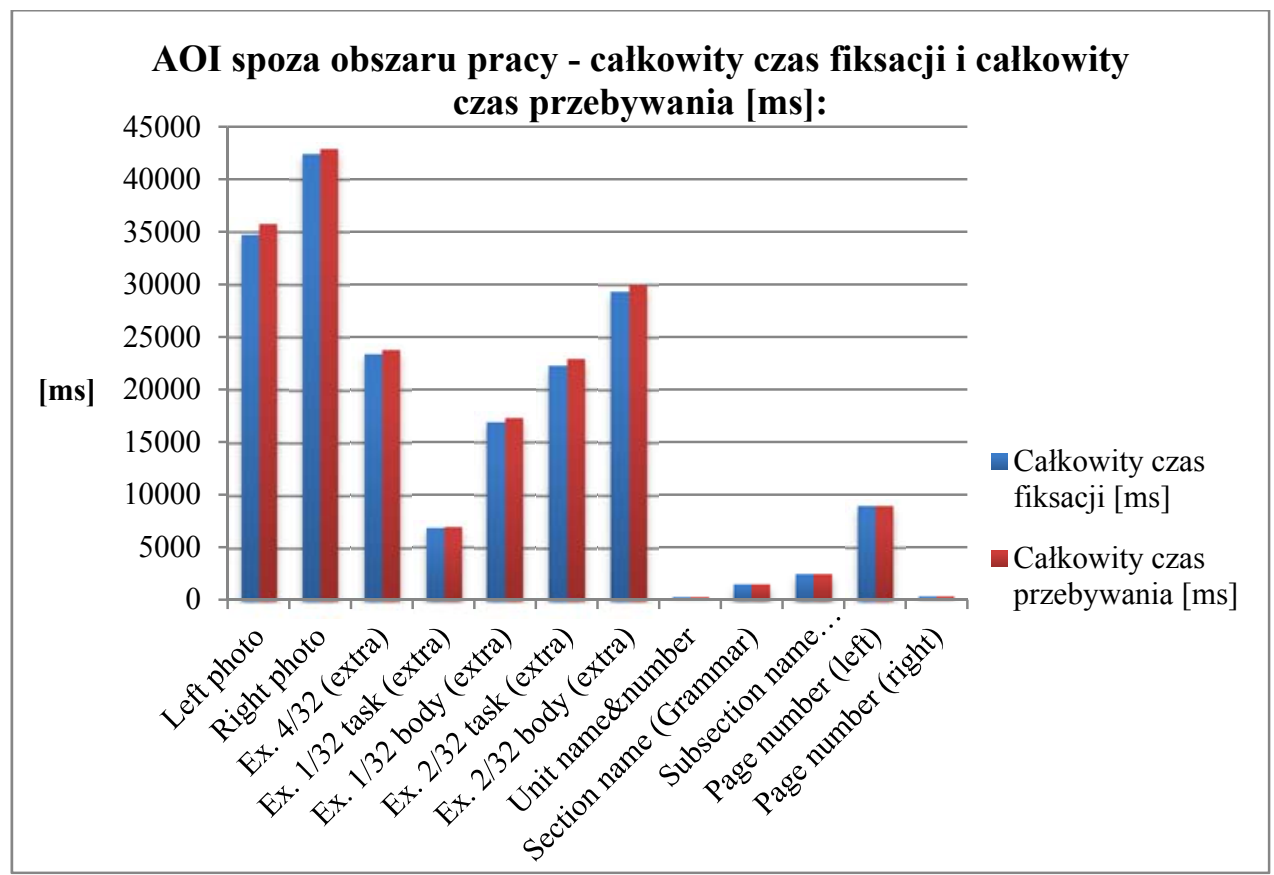

Rys. 6 Calkowity czas fiksacji i calkowity czas przebywania [ms] dla AOI spoza obszaru pracy, materiat czarno-biaty, drugie badanie pilotażowe.

W przypadku AOI spoza obszaru pracy na uwagę zasługuje wysoka wartość (w porównaniu do pozostałych AOI z tej grupy) całkowitego czasu fiksacji i całkowitego czasu przebywania dla zdjęcia przedstawiającego twarz mężczyzny (Dorian Gray) i umieszczonego po prawej stronie nad tekstem oraz dla zdjęcia nad tekstem po lewej stronie. Co istotne, również dla zadania 4/32 wartości parametrów są dość wysokie. Wszystkie te trzy obszary zainteresowania nie mają związku z wykonywanymi poleceniami, ale leżą w bardzo bliskiej odległości od obszarów pracy (graniczą z tymi obszarami). Stosunkowo dużą wartość parametrów dla AOI Ex. 2/32 body (extra) można łączyć z faktem powtórzonej numeracji zadań, co okazało się wprowadzać niektórych badanych w błąd. Warto zauważyć, że mniejsze wartości parametrów odnotowano na poleceniu do tego zadania, Ex. 2/32 task (extra), co może prowadzić do wniosku, że część badanych uczniów nie czytała poleceń.

W materiale kolorowym natomiast wartości liczbowe dla obydwu parametrów rozkładają się następująco: 


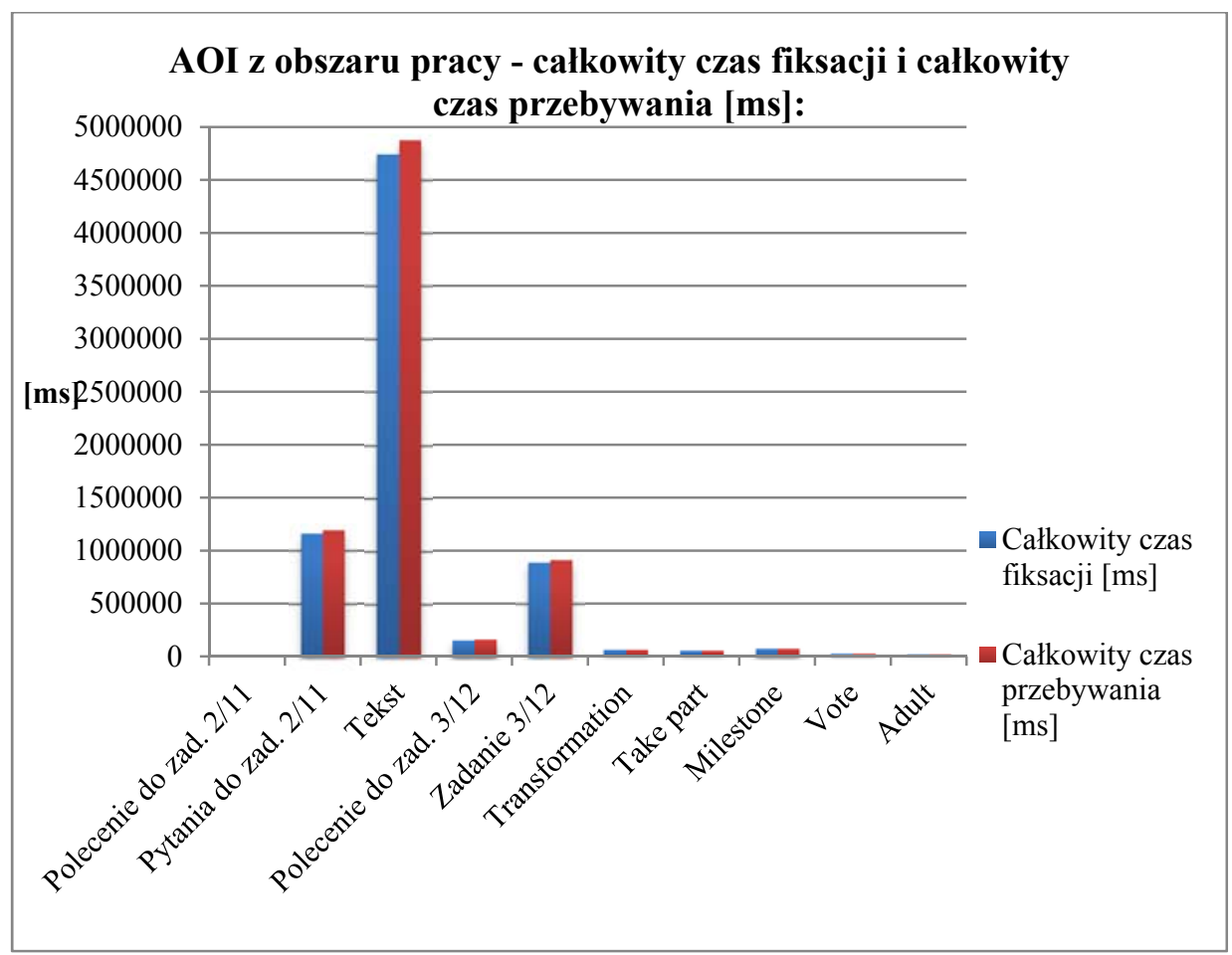

Rys. 7 Całkowity czas fiksacji i calkowity czas przebywania [ms] dla AOI z obszaru pracy, materiat kolorowy, drugie badanie pilotażowe.

$\mathrm{Na}$ powyższym wykresie wyraźnie zauważalna jest dysproporcja między AOI Pytania do zad. 2/11 i Zadanie 3/12 a pozostałymi obszarami (pomijam tu AOI Tekst, dla którego wszelkie wartości liczbowe z opisanych powyżej powodów są bardzo wysokie). Tak duże wartości na tych dwóch obszarach nie powinny dziwić ze względu na to, że obydwa te AOI były ściśle związane z poleceniami (na tych obszarach należało pracować udzielając odpowiedzi). Zaskakują natomiast tak małe wartości tych parametrów przede wszystkim dla AOI Polecenie do zad. 2/11, ale również dla Polecenie do zad. 3/12. 


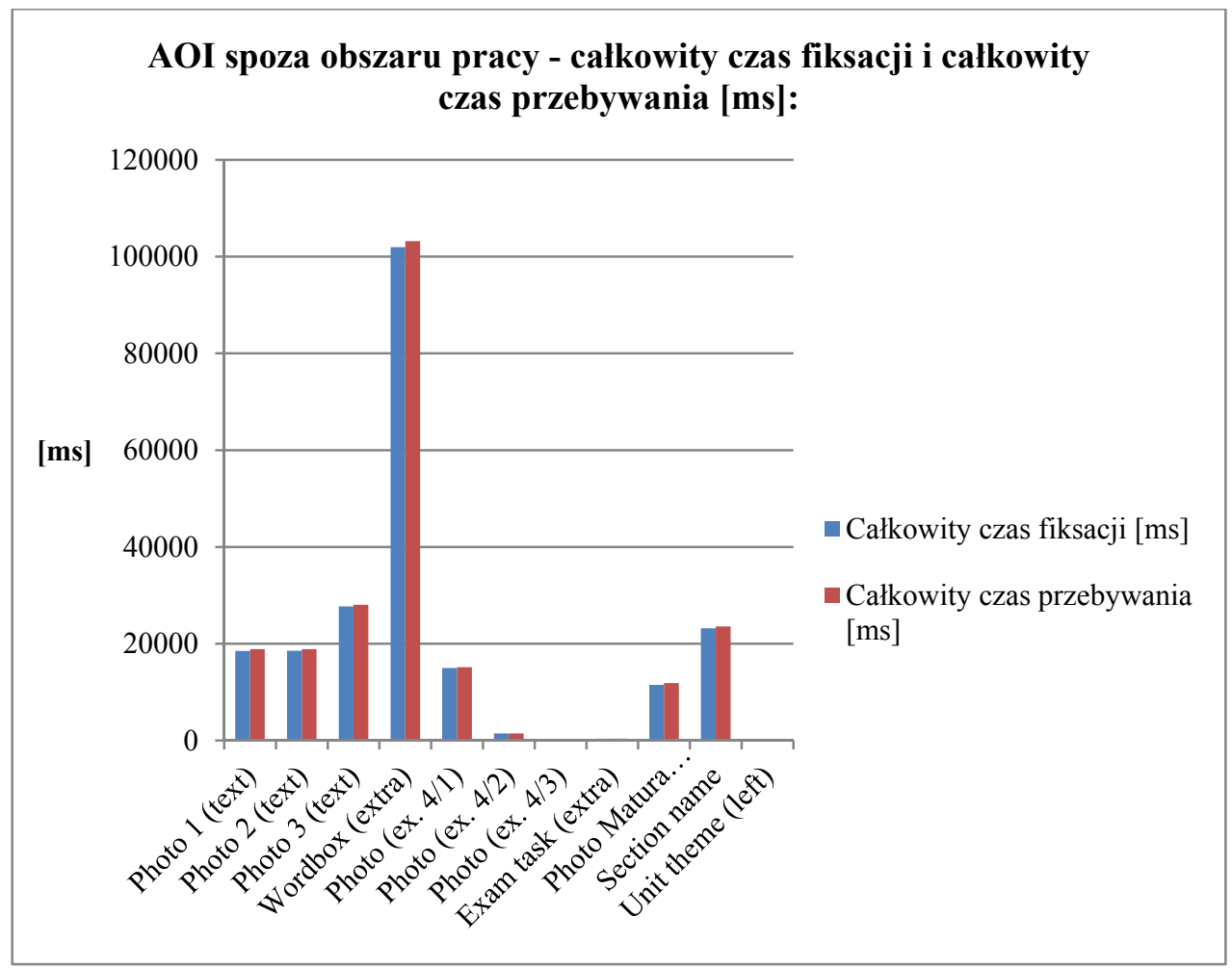

Rys. 8 Całkowity czas fiksacji i calkowity czas przebywania [ms] dla AOI spoza obszaru pracy, materiat kolorowy, drugie badanie pilotażowe.

Na powyższym wykresie widać, że wśród AOI spoza obszaru pracy wyróżnia się zarejestrowanym czasem fiksacji i długością przebywania na niej wzrokiem tabelka umieszczona pod tekstem (Wordbox extra). Widać również dominację zdjęć nad tekstem, w szczególności zdjęcia po prawej stronie (Photo 3 text), zdjęcia z ćw. 4 (Photo ex. 4/1) oraz nagłówka z nazwą podsekcji (górny margines, Section name) i zdjęcia z ćw. 5 (Photo Matura extra) pod względem wartości tych parametrów. Należy w tym miejscu jeszcze raz podkreślić, że AOI Wordbox extra oraz Photo (ex. 4/1) nie należą do obszaru pracy, ale są AOI spoza obszaru pracy leżącymi bardzo blisko (na granicy) obszaru pracy.

\subsubsection{Uczniowskie strategie realizacji zadania}

Jak wspomniano wcześniej, uczniowie przystępujący do badania otrzymywali ustne polecenie „Wykonaj zadanie X. Odpowiedzi podaj na głos”. Bazując na własnym doświadczeniu sądziłam, że w reakcji na tak brzmiące polecenie uczniowie wybiorą jedną z dwóch zakładanych przeze mnie strategii realizacji polecenia, czyli:

- strategia A - 1) odnajdą zadanie X; 2) przeczytają polecenie do zadania X; 3) przeczytają pytania do zadania X; 4) przeczytają cały tekst (ten krok nie jest konieczny w przypadku drugiego z poleceń w obydwu materiałach); 5) rozpoczną udzielanie odpowiedzi, powracając, o ile to potrzebne, do tekstu; 
- strategia B - te same kroki z odwróceniem kolejności punktów 3) i 4) (tzn. badani najpierw przeczytają cały tekst, a następnie przejdą do przeczytania pytań).

W celu zbadania faktycznej kolejności realizacji polecenia wykorzystałam macierz przejść (ang. transition matrix) pomiędzy obszarami zainteresowania, wygenerowaną (dla każdego z wyświetlanych materiałów) zbiorczo dla wszystkich badanych, oraz kolejność „wydarzeń wzrokowych”, wygenerowaną dla każdego z badanych osobno. Dane dla tych dwóch parametrów pokazały, że moje oczekiwania dotyczące strategii nie znalazły potwierdzenia w praktyce.

\subsubsection{Macierz przejść między AOI}

Macierz przejść jest narzędziem generowanym przez oprogramowanie. Pozwala ona na przeanalizowanie liczby przeniesień wzroku między konkretnymi obszarami zainteresowania. Dane te można otrzymać dla wybranych lub wszystkich AOI oraz dla wybranych lub wszystkich badanych. Należy pamiętać, że w macierzy przejść nie ma informacji na temat kolejności i momentu wykonywania konkretnych czynności wzrokowych. Takie dane dostępne są w szczegółowych danych liczbowych i reprezentacjach graficznych prezentowanych $\mathrm{w}$ podrozdziale 2.4.2.2. Ze względu na brak takich informacji w macierzy przejść prezentowane poniżej dane są danymi zbiorczymi dla wszystkich badanych. Uzasadnieniem takiej ich prezentacji jest dążenie do wyciągnięcia wniosków ogólnych dla badanej grupy, a nie analiza indywidualnych zachowań poszczególnych probantów. Ponadto analiza indywidualna ma większe zastosowanie tam, gdzie można otrzymać informacje w macierzy przejść niewystępujące, tj. czas i kolejność danych czynności wzrokowych.

Poniższa macierz przejść jest tabelarycznym przedstawieniem całkowitej liczby przeniesień wzroku z jednego AOI do drugiego AOI przez wszystkich badanych łącznie. W przedstawionej poniżej macierzy literom alfabetu odpowiadają zamieszczone po lewej stronie nazwy obszarów zainteresowania (np. A oznacza Polecenie do zad. 2/31, T - Subsection name (Articles)). Pogrubione zostały te nazwy AOI, odpowiadające im symbole literowe oraz wartości liczbowe, które odnoszą się do AOI z obszaru pracy, aby łatwo odróżnić je od tych spoza obszaru pracy (tj. bez pogrubienia). Macierz pokazuje liczbę przejść wzrokiem z obszarów z lewej kolumny pionowej do obszarów z górnego wiersza (np. z pionowego G, tj. z AOI Search for, do poziomego E, tj. do AOI Zadanie 3/32 łącznie przeniesiono wzrok 9 razy). Kolorem czerwonym zaznaczono duże wartości liczbowe. Obszar pod nazwą White Space to wszystkie te fragmenty materiału, które nie zostały przeze mnie oznaczone jako obszary zainteresowania (innymi słowy jest to wszystko oprócz AOI). Przedstawione wartości liczbowe są danymi zbiorczymi dla wszystkich badanych. 

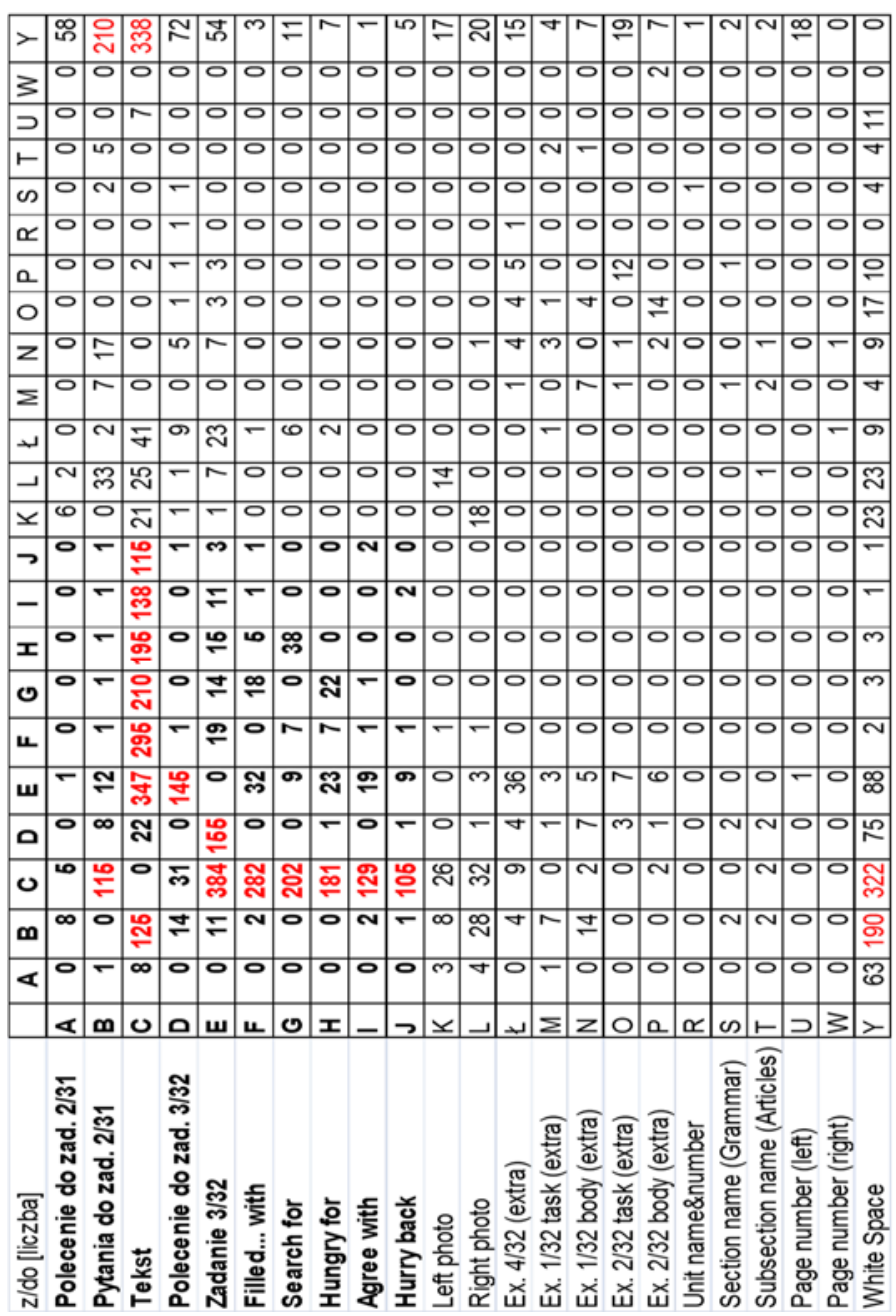

Tab. 3 Macierz przejść między AOI, materiat czarno-bialy, drugie badanie pilotażowe.

$\mathrm{Z}$ powyższego wynika, że $\mathrm{w}$ materiale czarno-białym najwięcej przeniesień wzroku odbywało się z obszaru Tekst do treści zadania 3 (Zadanie 3/32) oraz do czasowników wytłuszczonych w tekście (i będących przedmiotem zadania 3 ) oraz do pytań do zad. 2/31, jak również w kierunku przeciwnym. Jeśli chodzi o czynności wzrokowe w kierunku z lub do AOI nienależących do obszaru pracy, to uwagę należy zwrócić na takie obszary i kierunki jak: zdjęcia nad tekstem (Right photo, Left photo); zadanie nr 4 (Ex. 4/32 extra) w kierunku treści zadania 3; treść zadania 1/32 (Ex. 1/32 body extra) w kierunku pytań do zadania $2 / 31$ i odwrotnie; polecenie do zad. 2/32 (Ex. 2/32 task extra) w kierunku treści tego zadania (Ex. 2/32 body extra) i odwrotnie. Dwa ostatnie kierunki mają związek z mylącą, powtarzającą się numeracją zadań, która, jak zostało to już wcześniej zauważone, wprowadziła część badanych w błąd. Przeniesienia wzroku z innych AOI w zasadzie nie są istotne, ponieważ albo nie występowały, albo było ich bardzo niewiele. 
Poniższą tabelę, przedstawiającą podobne dane dla materiału kolorowego, należy czytać w ten sam sposób. Kolorem czerwonym zaznaczono duże wartości liczbowe. Przedstawione wartości liczbowe są danymi zbiorczymi dla wszystkich badanych.

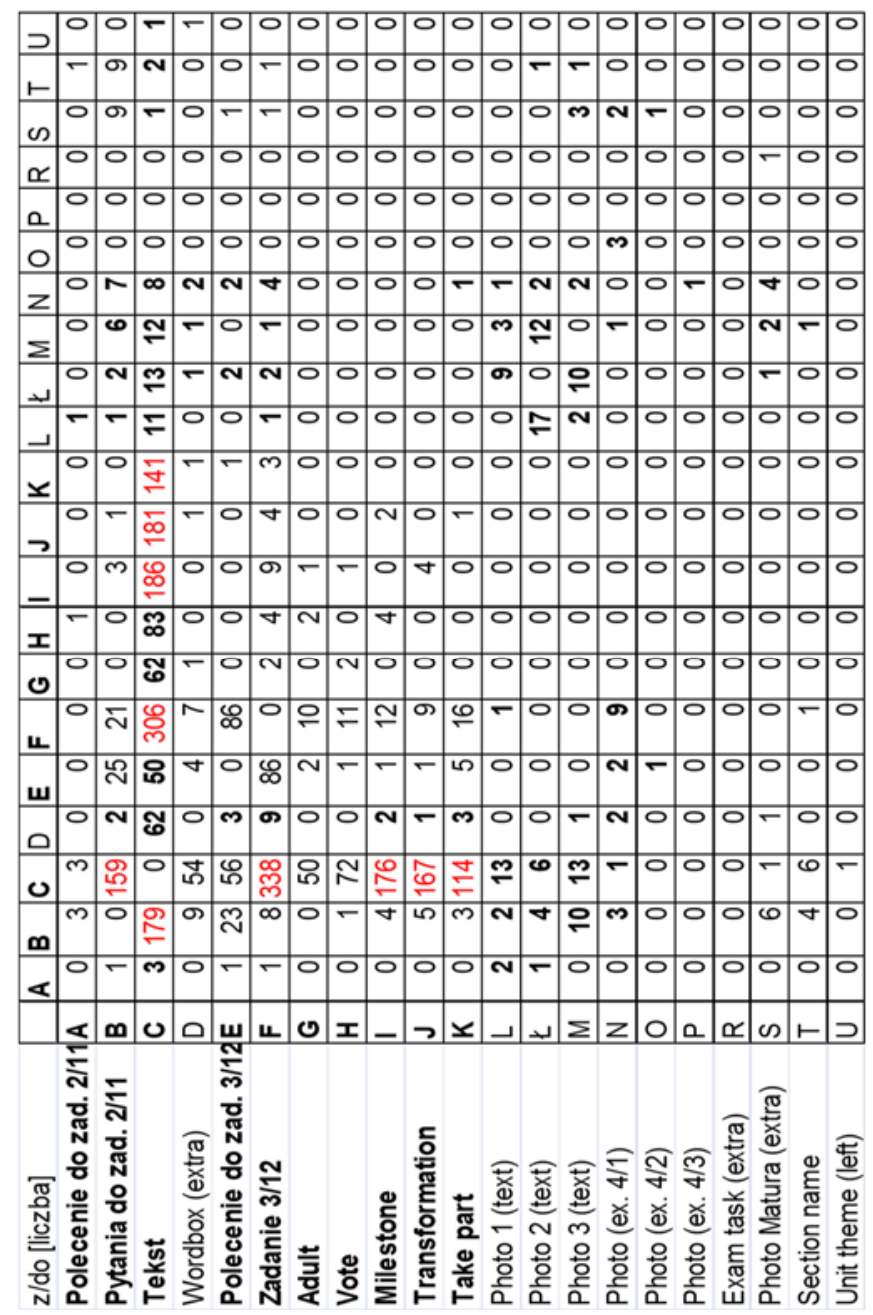

Tab. 4 Macierz przejść między AOI, materiat kolorowy, drugie badanie pilotażowe.

W przypadku materiału kolorowego również należy zwrócić uwagę na dużą liczbę przeniesień wzroku z obszaru Tekst na obszar pytań do zadania $2 / 11$, treści zadania $3 / 12$ oraz słów wytłuszczonych w tekście, będących przedmiotem zadania 3/12. Tym razem jednak dla 3 spośród pięciu tych słów (tj. milestone, transformation, take part) odnotowana liczba przeniesień wzroku jest większa niż w przypadku dwóch pozostałych (tj. adult, vote). Można ten fakt tłumaczyć długością i nieznajomością dwóch pierwszych oraz tym, że trzecie słowo składało się z dwóch elementów (czasownik frazowy take part) i że odpowiedzi należało podać na głos (tj. nale- 
żało poradzić sobie z wymówieniem tych słów). $\mathrm{Z}$ wielu badań nad tekstem wynika, że słowa długie, wieloliterowe często wymagają więcej niż jednej fiksacji na sobie. Ponadto w przypadku słów nieznanych, które dodatkowo należy wypowiedzieć na głos, również wzrasta liczba fiksacji i ich czas (K. Rayner 1998, K. Rayner/ G.W. McConkie 1976, K. Rayner/ S.A. Duffy 1986). Badani przenosili często wzrok z AOI Tekst również na tabelkę ze słówkami pod tekstem (Wordbox extra) oraz na obszar polecenia do zadania 3/12 i odwrotnie. W macierzy widać także, że badani często powracali wzrokiem do tekstu $\mathrm{w}$ trakcie wykonywania poleceń (przede wszystkim kierunek Zadanie 3/12 - Tekst i odwrotnie, ale również Pytania do zad. $2 / 11$ - Tekst i odwrotnie). Wśród AOI spoza obszaru pracy nie wyróżnia się w szczególny sposób żaden - kilkanaście przeniesień wzroku odnotowano jedynie w kierunkach zdjęcie nr 3 nad tekstem (Photo 3 text) - tekst i odwrotnie oraz pomiędzy zdjęciami nad tekstem.

\subsubsection{Kolejność „wydarzeń wzrokowych”}

Kolejność wydarzeń wzrokowych (ang. AOI sequence chart) może być odtwarzana na podstawie graficznej reprezentacji (patrz schematy poniżej), jak również na podstawie analizy danych liczbowych (ang. event statistics) generowanych przez oprogramowanie. W odróżnieniu od macierzy przejść, ten parametr zawiera informacje dotyczące momentu wykonywania konkretnej czynności wzrokowej oraz m.in. czasu jej trwania, dlatego też należy analizować go indywidualnie dla każdego badanego, a następnie wyciągać zbiorcze wnioski.

W celu zobrazowania wyglądu otrzymywanych danych graficznych poniżej zamieszczono dwa przykładowe zapisy ,wydarzeń wzrokowych” w czasie (AOI sequence chart). Zapisy te zostały wygenerowane osobno dla każdego $\mathrm{z}$ badanych. Poniższe dwa pokazują kolejność ,,wydarzeń wzrokowych” w materiale kolorowym u osoby, która opanowała techniki sprawnej pracy z tekstem (Rys. 7) oraz u osoby, która była najmniej sprawna w tym obszarze (Rys. 8). Po lewej stronie zostały zamieszczone nazwy poszczególnych AOI. Oś pozioma jest osią czasu [ms]. 
AOls vs. Timt

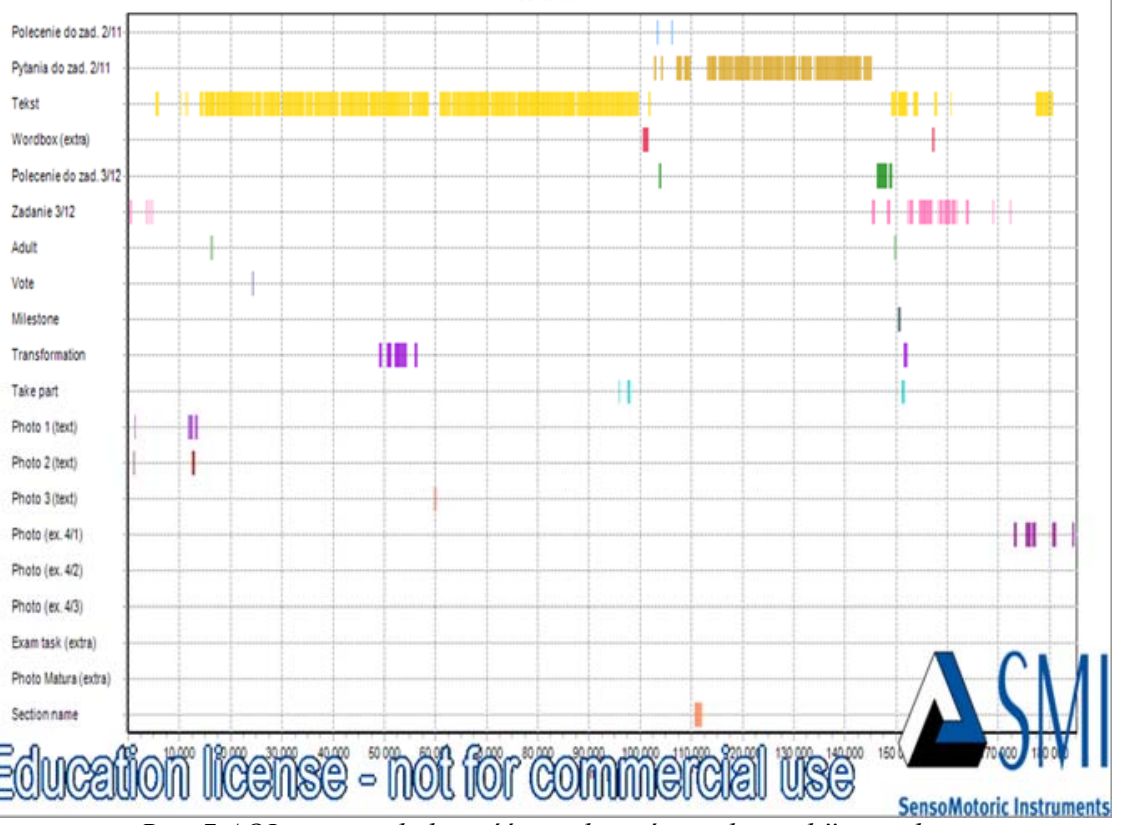

Rys. 7 AOI vs czas - kolejność ,,wydarzeń wzrokowych" u osoby,

która opanowata techniki sprawnej pracy z tekstem (materiat kolorowy). Calkowity czas wykonania obydwu zadań $=3$ min. 5,47 sek.

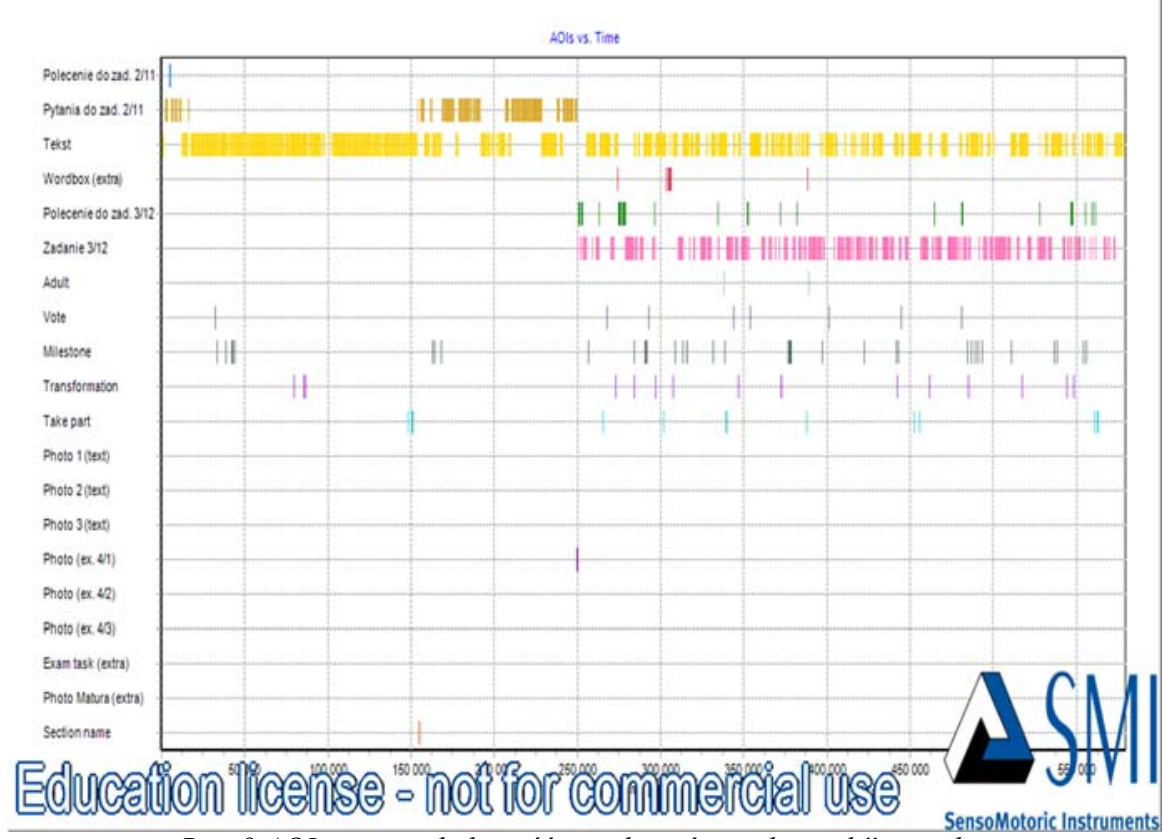

Rys. 8 AOI vs czas - kolejność ,wydarzeń wzrokowych” u osoby,

która najmniej sprawnie pracowata z tekstem (materiat kolorowy).

Catkowity czas wykonania obydwu zadań $=9$ min. 40 sek. 
Tym, co zwraca uwagę jest trzykrotnie szybsze wykonanie zadań przez osobę sprawniej pracującą z tekstem. Ponadto obydwa rysunki różni liczba i gęstość pionowych kresek, oznaczających skupienie wzroku na danym AOI. Każdy kolor oznacza inny ze zdefiniowanych obszarów zainteresowania. Na rys. 7 widać, że badany nie przeczytał polecenia do zad. $2 / 11$, natomiast przeczytał od razu cały tekst, zaledwie kilkukrotnie odchodząc w trakcie czytania wzrokiem do innych AOI. Po przeczytaniu tekstu badany udzielił odpowiedzi na pytania (bez powracania wzrokiem do tekstu). Następnie przeczytał polecenie do zad. 3/12 i przystąpił do udzielania odpowiedzi, kilkukrotnie powracając wzrokiem do tekstu. Na rys. 8 widać chaos w pracy z tekstem - badany przeczytał polecenie, następnie przeniósł wzrok na pytania do tekstu, zaczął czytać tekst, po czym zaczął przenosić wzrok pomiędzy tekstem a pytaniami (w tym czasie udzielał odpowiedzi). Po zakończeniu pracy z pierwszym poleceniem badany wielokrotnie przechodził wzrokiem między poleceniem do kolejnego zadania, jego treścią i tekstem, koncentrując uwagę wzrokową na słowach wyróżnionych w tekście, które były przedmiotem tego zadania.

$\mathrm{Na}$ podstawie analizy indywidualnych reprezentacji graficznych tego typu dla wszystkich badanych i dla obydwu materiałów można wyciągnąć ogólne wnioski dotyczące strategii wybieranych przez uczniów $\mathrm{w}$ trakcie pracy $\mathrm{z}$ wyświetlanym materiałem podręcznikowym. I tak, w przypadku materiału czarno-białego okazało się, że:

1) zakładaną przeze mnie strategię A (tj. odnalezienie zadania $X$, przeczytanie polecenia do zadania $X$, przeczytanie pytań do zadania $X$, przeczytanie całego tekstu (ten krok nie jest konieczny w przypadku drugiego $\mathrm{z}$ poleceń $\mathrm{w}$ obydwu materiałach), rozpoczęcie udzielania odpowiedzi, powracając, o ile to potrzebne, do tekstu) wybrało 5 osób; strategię B (tj. odnalezienie zadania $\mathrm{X}$, przeczytanie polecenia do zadania $\mathrm{X}$, przeczytanie całego tekstu (ten krok nie jest konieczny w przypadku drugiego z poleceń w obydwu materiałach), przeczytanie pytań do zadania $X$, rozpoczęcie udzielania odpowiedzi, powracając, o ile to potrzebne, do tekstu) wybrało 6 osób. Należy zauważyć, że w tej grupie 11 osób ( $\mathrm{tj}$. tych, którzy wybrali strategię A lub B) wszystkie znały język angielski na poziomie zbliżonym do Upper-Intermediate (poziom wyższy średniozaawansowany), co oznacza, że nie miały one trudności ze zrozumieniem poleceń, treści zadań, a przede wszystkim samego tekstu, co niewątpliwie miało wpływ na percepcję informacji w nim zawartych. W celu sprawdzenia poziomu retencji informacji należałoby wziąć pod uwagę poprawność udzielonych odpowiedzi, co nie jest jednak przedmiotem niniejszego artykułu;

2) dwoje badanych mylnie odszukało polecenie do zadania $2 / 32$ zamiast $2 / 31$, co było wynikiem zastosowanej powtarzającej się numeracji ćwiczeń;

3) tylko 3 badane osoby w ogóle nie odchodziły wzrokiem do obszarów zainteresowania spoza obszarów pracy. Innymi słowy, $85 \%$ badanych w mniejszym lub większym stopniu skupiało swój wzrok na obszarach nieistotnych z punktu widzenia wykonywanych zadań. Kolejne 3 badane osoby w minimalnym stopniu odchodziły wzrokiem do AOI spoza obszaru pracy; 
4) 10 osób pracowało $\mathrm{z}$ tekstem $\mathrm{w}$ sposób nieuporządkowany, tzn. $\mathrm{w}$ trakcie wykonywania poleceń odchodziły wzrokiem do innych AOI (najczęściej były to zdjęcia nad tekstem), przenosiło wzrok z tekstu na pytania i odwrotnie, nie czytało poleceń (najczęściej polecenia do zadania 2/31), przed przystąpieniem do pracy z tekstem błądziło wzrokiem po całym materiale.

$\mathrm{W}$ przypadku materiału kolorowego natomiast zaobserwowano następujące zachowania wzrokowe uczniów w trakcie pracy z materiałem:

1) zarówno zakładaną strategię A, jak i strategię B wybrała w materiale kolorowym tylko 1 osoba;

2) tylko jedna osoba nie przenosiła wzroku do innych AOI (spoza obszaru pracy, jak również tych $\mathrm{z}$ obszaru pracy, ale niezwiązanych $\mathrm{z}$ wykonywanym $\mathrm{w}$ danym momencie poleceniem), a 3 osoby w minimalnym stopniu przenosiły wzrok do innych AOI;

3) 14 osób przystąpiło do wykonywania zadania $2 / 11$ bez zapoznania się z poleceniem do niego; polecenie do kolejnego wykonywanego zadania przeczytali (a przynajmniej skupili na nim wzrok) wszyscy badani;

4) 19 osób wykonywało polecenia chaotycznie, wielokrotnie przenosząc wzrok z obszaru tekstu na obszar pytań i odwrotnie.

Powyższe pokazuje różnice $\mathrm{w}$ zachowaniach wzrokowych badanych uczniów w obydwu wyświetlanych materiałach. Na podstawie analizy można stwierdzić, że podczas pracy z materiałem czarno-białym uczniowie byli mniej podatni na odchodzenie wzrokiem z obszaru pracy do obszarów niezwiązanych z wykonywanymi poleceniami. Ponadto $\mathrm{w}$ materiale czarno-białym zauważalna jest różnica $\mathrm{w}$ liczbie osób czytających polecenia do zadań w porównaniu z poleceniami z materiału kolorowego, w którym polecenie do zad. 2/11 odwiedziło wzrokiem 14 z 21 osób (7 osób zrobiło to na samym początku, 9 powróciło wzrokiem do tego obszaru; średnia rewizyt, $\mathrm{tj}$. średnia liczba wszystkich ponownych (powrotnych) fiksacji wszystkich badanych odnotowana na tym AOI $=0,4$ ), polecenie do zad. 3/12 odwiedził każdy (21 osób powróciło; średnia rewizyt $=12,5)$. W przypadku materiału kolorowego odnotowano więcej odejść wzrokiem w trakcie wykonywania polecenia $\mathrm{z}$ tekstem do AOI spoza obszaru pracy.

\section{Wnioski}

Przedstawione wyniki badań prowadzą do kilku bardzo istotnych wniosków. Po pierwsze, znana forma zadania powoduje, że uczniowie nie czytają polecenia. Obserwacja ta znajduje potwierdzenie w liczbie fiksacji oraz całkowitym czasie fiksacji i całkowitym czasie przebywania wzrokiem na poleceniach do zadan typu prawda/fałsz (True/False), których elementem składowym jest charakterystyczna tabelka. Wprawny, doświadczony uczeń tylko na podstawie spojrzenia na taką tabelkę jest w stanie wywnioskować, na czym polega zadanie. Takie wnioskowanie może jednak być zgubne w sytuacji, w której polecenie nie sprowadza się tylko i wyłącznie do stwierdzenia, czy podane zdanie jest prawdą, czy fałszem lub gdy uczeń niewłaściwie oceni rodzaj zadania np. w trakcie egzaminu maturalnego. Należy jednak wziąć pod uwagę fakt, że w obydwu wyświetlanych materiałach należało wykonać zadania 
tego samego typu, co mogło mieć wpływ na decyzję o nieczytaniu poleceń w materiale kolorowym (wyświetlanym jako drugi w kolejności), a jedynie wnioskowanie na podstawie zbieżności graficznej.

Po drugie, badania pokazują, że część uczniów nie potrafi skutecznie pracować z tekstem. Spostrzeżenie to dotyczy nie tylko uczniów, którzy słabiej znają język angielski.

Po trzecie, rejony graniczące $z$ obszarem pracy mają znaczenie. Badania pokazują, że na te rejony uczeń zwraca swoją uwagę wzrokową, dlatego też warto je rozsądnie wykorzystać, np. umieszczając w tych obszarach treści istotne dla procesu glottodydaktycznego.

Po czwarte, elementy nierelewantne (nieistotne) glottodydaktycznie częściowo odciągają uwagę uczniów. Do takich elementów zaliczam wszystkie dodatki graficzne, które nie mają uzasadnienia w treści zadań. Należy jednak pamiętać, że definiowanie elementów nierelewantnych wymaga znajomości analizowanego materiału przez badacza.

Po piąte, odnotowano różnice w sposobie skupienia uwagi na tekście. Część uczniów pracowała metodycznie, skupiając się na wybranych fragmentach tekstu/zadań, a część chaotycznie przeskakiwała pomiędzy różnymi obszarami materiałów. Na te różnice ma niewątpliwie wpływ wspominany już wcześniej poziom znajomości języka obcego, dysfunkcje, ale również dodatkowe sprawności lub po prostu brak wiedzy na temat sposobów pracy z tekstem.

\section{Bibilografia}

Andrychowicz-Trojanowska, A. (2016), Perception of textbook material by dyslectic and non-dyslectic students: an eye-tracking experiment, (w:) Linguistica Silesiana, 37, 409-427.

Andrychowicz-Trojanowska, A. (2015a), Materiat glottodydaktyczny w podręczniku do nauki języka angielskiego dla szkót średnich a jego odbiorca, (w:) Lingwistyka Stosowana/ Applied Linguistics/ Angewandte Linguistik, 14, 1-15. (www.ls.uw.edu.pl/documents

/7276721/13367523/1+Lingwistyka+Stosowana+14+Agnieszka+AndrychowiczTrojanowska.pdf; pobrano 04.07.2016).

Andrychowicz-Trojanowska, A. (2015b), Uwaga wzrokowa ucznia $w$ pracy z podręcznikiem do nauki języka angielskiego, (w:) Komunikacja Specjalistyczna, 9, 104-124.

Duchowski, A. (2007), Eye Tracking Methodology. New York.

Engbert, R. (2006), Microsaccades: A microcosm for research on oculomotor control, attention, and visual perception, (w:) Progress in Brain Research, 154, 177192.

Engbert, R./ R. Kliegl (2004), Microsaccades Keep the Eyes' Balance During Fixation, (w:) Psychological Science, 15, 431-436.

Francuz, P. (2013), Imagia. W kierunku neurokognitywnej teorii obrazu. Lublin.

Grucza, S. (2011), Lingwistyka antropocentryczna a badania okulograficzne, (w:) 
Lingwistyka Stosowana/ Applied Linguistics/ Angewandte Linguistik, 4, 149162. (www.1:uw.edu.pl/documents/7276721/11203934/LS4_2011_art_ GRUCZA.pdf) (Pobrano 19.06.2015).

Holmqvist, K./ M. Nyström/ R. Andersson/ R. Dewhurst/ H. Jarodzka/ J. van de Weijer (2011), Eye Tracking. A comprehensive guide to methods and measures. New York.

Leigh, R.J./ D.S. Zee (2006), The neurology of eye movements. New York.

Martinez-Conde, S./ S.L. Macknik/ D.H. Hubel (2004), The role of fixational eye movements in visual perception, (w:) Nature Reviews Neuroscience, 5, 229-240.

Martinez-Conde, S./ S.L. Macknik/ X.G. Troncoso/ D.H. Hubel (2009), Microsaccades: a neurophysiological analysis, (w:) Trends in Neurosciences, 32, 463475.

Płużyczka, M. (2015), Thumaczenie a vista. Rozważania teoretyczne i badania eyetrackingowe. Warszawa.

Quintana J./ J. Sosnowska/ D. Gryca (2011), Oxford Excellence for Matura. New Exam Builder. Oxford.

Rayner, K. (1998), Eye Movements in Reading and Information Processing: 20 Years of Research, (w:) Psychological Bulletin, 124/3, 372-422.

Rayner, K./S.A. Duffy (1986), Lexical complexity and fixation times in reading: Effects of word frequency, verb complexity, and lexical ambiguity, (w:) Memory \& Cognition, 14, 191-201.

Rayner, K./ G.W. McConkie (1976), What Guides a Reader's Eye Movements?, (w:) Vision Researc,h 16, 829-837.

Rolfs, M. (2009), Microsaccades: Small steps on a long way, (w:) Vision Research, 49, 2415-2441.

Soluch, P./ A. Tarnowski (2013), O metodologii badań eyetrackingowych, (w:) Lingwistyka Stosowana, Applied Linguistics/ Angewandte Linguistic, 7, 115134. (www.ls.uw.edu.pl/documents/ 7276721/11196346/LS7_2013_art_Soluch_Tarnowski.pdf; pobrano 19.06.2015). 